ISSN 0258-7122

Bangladesh J. Agril. Res. 40(3): 409-420, September 2015

\title{
PROFITABILITY OF BETEL LEAF (Piper betle L.) CULTIVATION IN SOME SELECTED SITES OF BANGLADESH
}

\author{
Q. M. S. ISLAM ${ }^{1}$, M. A. MATIN ${ }^{2}$, M. A. RASHID ${ }^{3}$ \\ M. S. HOQ ${ }^{4}$ AND MONIRUZZAMAN ${ }^{5}$
}

\begin{abstract}
The study was conducted in four betel leaf growing areas, namely Barisal, Chittagong, Rajshahi and Kustia district during 2013-14 to assess the cultivation practices, physical productivity, profitability, and to explore the constraints to betel leaf cultivation. The study has been designed to investigate the economics of betel leaf production considering intensive cultivated areas for recent information in Bangladesh. From each district, two upazilas were selected considering the concentration of betel leaf growers and easy access. Also from each upazila, two blocks and from each block 20 farmers were selected with the consultation of Upazila Agriculture Officer and Sub Assistant Agriculture Officer. The study revealed that betel leaf cultivation was profitable in the study areas, although BCR in the first and second years was below one which was due to high initial cost. The highest yield and gross return of betel leaf cultivation were in the fifth year. The benefit cost ratio was found highest in 6-10 year followed by $5^{\text {th }}$ and $11-15$ year. The benefit cost ratio at $12 \%, 15 \%$ and $20 \%$ rate of interest were $1.27,1.25$ and 1.21 respectively. Internal rate of return (IRR) was calculated $62 \%$ in current situation, IRR $37 \%$ was found by $10 \%$ decrease of return and $39 \%$ by $10 \%$ increase of cost. The problems like leaf rot disease, high price of boroj materials, low price of betel leaf, high price of oilcake, etc. were facing by the betel leaf farmers.
\end{abstract}

Keywords: Betel leaf, BCR, IRR, NPV, Constraints.

\section{Introduction}

Betel leaf (Piper betle L.), locally known as Paan, is a masticatory having important socio-cultural and ceremonial uses in South and Southeast Asia, significant medicinal properties and nutritional values. The vine is native to Southeast Asia including Bangladesh which is thought to be one of the cradles of earliest agriculture. The betel leaf plant is an evergreen and perennial creeper, with glossy heart-shaped leaves and white catkin. It is a native of central and eastern Malaysia, which spread at a very early date throughout tropical Asia and later to Madagascar and East Africa (www.efymag.com/ admin/issuepdf/ Betel\%20Leaf_April-12.pdf).

Betel leaf a kind of pepper used in wrapping the pellets of betel nut and lime, is commonly chewed in the orient. Betel leaf is an important cash crop in our

\footnotetext{
${ }^{1-3}$ Principal Scientific Officer, ${ }^{4}$ Scientific Officer, ${ }^{5}$ Senior Scientific Officer, Agricultural Economics Division, BARI, Joydebpur, Gazipur, Bangladesh.
} 
country and is considered to be one of the ingredients for social entertainment. It has also a sharp taste and good smell, improves taste and appetite, tonic to the brain heart, liver, strengthens the teeth and clears the throat.

Table 1: Area and production of betel leaf in Bangladesh

\begin{tabular}{lcccc}
\hline Year & Area (ha) & Production (tons) & Yield (t/ha) \\
\hline $1995-96$ & 13943 & 71910 & 5.16 \\
$1996-97$ & 14595 & 77035 & 5.28 \\
$1997-98$ & 14832 & 79080 & 5.33 \\
$1998-99$ & 13820 & 73525 & 5.32 \\
$1999-00$ & 15063 & 78780 & 5.23 \\
$2000-01$ & 15346 & 82260 & 5.36 \\
$2001-02$ & 14696 & 80540 & 5.48 \\
$2002-03$ & 15472 & 83830 & 5.42 \\
$2003-04$ & 16480 & 93425 & 5.67 \\
$2004-05$ & 16771 & 93820 & 5.59 \\
$2005-06$ & 16275 & 97415 & 5.99 \\
$2006-07$ & 16536 & 101240 & 6.12 \\
$2007-08$ & 17346 & 97947 & 5.65 \\
$2008-09$ & 17643 & 105448 & 5.98 \\
$2009-10$ & 17871 & 91681 & 5.13 \\
$2010-11$ & 18247 & 105953 & 5.81 \\
\hline Mean & 15934 & 88368 & 5.53 \\
CV (\%) & 8.84 & 12.81 & 5.63 \\
Growth rate (\%) & 1.80 & 2.50 & 0.70 \\
\hline
\end{tabular}

Source: BBS, 2011

In 2010-11, the total betel leaf area was 18,247 ha (31\% higher than the area in 1995-96) with a production of $1,05,953$ tons ( $47 \%$ higher than the production in 1995-96) in Bangladesh. The area of this crop has been increasing at an increasing rate $(1.8 \%)$ over the years (Table 1). Betel leaf has become a promising commodity with an increasing trend of export every year (Anonymous, 1984).

The country may earn a huge amount of foreign currency every year by exporting betel leaf in different countries. However, data and information regarding betel leaf production and the status of local and international marketing system are scarce in the country. A very few studies were conducted (Ahmed, 1985; Islam and Elias 1991 and Moniruzzaman, et. al 2008) regarding the profitability and 
constraints to higher production as well as export potentiality of betel leaf production in Bangladesh. Earlier studies were conducted very limited areas and back dated. Thus, the present study has been designed to investigate the economics of betel leaf cultivation considering intensive cultivated areas. This study provides useful information to the policy makers to make policy guidelines for enhancing its production as well as its overall development in the near future. Therefore, the present study was undertaken with the following specific objectives:

1. To know the agronomic practices of betel leaf at growers level.

2. To determine the cost and return of betel leaf cultivation.

3. To estimate physical productivity and returns to investment in betel leaf cultivation, and

4. To find out the constraints of betel leaf cultivation at farm level.

\section{Methodology}

Study area and sampling technique: Multi-stage sampling technique was followed in this study. Four betel leaf growing districts namely Barisal, Chittagong, Rajshahi and Kustia were purposively selected. Again from each district, two upazilas were selected considering the concentration of betel leaf growers and easy access. Also from each upazila, two blocks were selected with the consultation of Upazila Agriculture Officer. A list of betel leaf growers from the selected blocks was prepared with the help of DAE personnel. Thus a total of $4 \times 2 \times 2 \times 16=256$ samples were randomly selected for the interview.

Data collection and period of study: Experienced field investigators with the direct supervision of the researchers collected data and information using a pretested interview schedule. Data were collected during the period of November to April, 2013-14.

Analytical technique: (a) Tabular method of analysis using descriptive statistics like average, percentage, ratio etc. was followed in presenting the results of the study. Data were categorized according to the age of betel leaf boroj. The age of the boroj were classified like $1^{\text {st }}$ year, $2^{\text {nd }}$ year, $3^{\text {rd }}$ year, $4^{\text {th }}$ year, $5^{\text {th }}$ year, $(6-10)^{\text {th }}$ year, (11-15) ${ }^{\text {th }}$ year and (16 and above) ${ }^{\text {th }}$ year. Because both cost of production and yield were vary year to year. Collected data were edited, summarized, tabulated and analyzed to fulfill the objectives of the study. (b) To measure the return to investment of betel leaf cultivating project appraisal technique. For measuring capital productivity, costs and returns were discounted at $12 \%, 15 \%$ and $20 \%$ rate of interest. The Benefit cost ratio (BCR), Net present value(NPV) and Internal rate of return(IRR) in betel leaf cultivation were calculated with the help of following formula. 
Net present Value $=\sum_{t=1}^{t=n} \frac{B_{t}-C_{t}}{(1+i)^{t}}$
Benefit cost ratio $=\frac{\sum_{t=1}^{t=n} \frac{B_{t}}{(1+t)^{t}}}{\sum_{t=1}^{t=n} \frac{C_{t}}{(1+i)^{t}}}$

\begin{tabular}{|c|c|c|c|c|c|}
\hline Internal & re & & $\begin{array}{l}\text { Difference } \\
\text { between }\end{array}$ & & $\begin{array}{l}\text { Present worth of incremental net } \\
\text { benefit stream (cash flow) at the } \\
\text { lower discount rate }\end{array}$ \\
\hline $\begin{array}{l}\text { Rate of } \\
\text { Return } \\
(\text { IRR })=\end{array}$ & $\begin{array}{l}\text { discount } \\
\text { rate }\end{array}$ & + & $\begin{array}{l}\text { the } \\
\text { discount } \\
\text { rates }\end{array}$ & $\times$ & $\begin{array}{l}\text { Sum of the present worth of the } \\
\text { incremental net benefit streams } \\
\text { (cash flows) at the two discount } \\
\text { rates, signs ignored }\end{array}$ \\
\hline
\end{tabular}

Where, $\quad B_{t}=$ Total benefit $(\mathrm{Tk} / \mathrm{ha})$ in $\mathrm{t}^{\text {th }}$ year

$\mathrm{C}_{\mathrm{t}}=$ Total cost $(\mathrm{Tk} / \mathrm{ha})$ in $\mathrm{t}^{\text {th }}$ year

$\mathrm{t}=$ Number of year

$\mathrm{i}=$ interest (discount) rate.

\section{Results and Discussion}

\section{Agronomic practices of betel leaf cultivation}

Respondent farmers did not plough their land for betel leaf cultivation. They prepared their land by spading. The most appropriate planting time of the betel leaf is at the end of the rainy season mostly from July to October by the farmers. The respondent farmers used betel leaf vine as seed which was mostly local variety. Within local varieties, farmers mainly cultivated Mohanali, Chailtagota and Cherifuli in Barisal, Mithapaan, Dholshi in Chittagong, Banglapaan, Mithapaan in Rajshahi and Mistipaan, Khilipaan in Kustia district. Modern varieties of betel leaf are not available in the study areas. The average number of betel leaf seed (vine) was found to be 123845 to 172841 numbers per hectare. The average plant to plant distance was found $15.24-20.32 \mathrm{~cm}$ and line to line spacing of betel leaf vine were found to be 45.72-55.88 $\mathrm{cm}$ in Barisal and Chittagong. But in Rajshahi and Kustia the line to line spacing were found $81.28-91.44 \mathrm{~cm}$. The average number of earthing up, application of oilcake, weeding, spraying and irrigation were $1.96,4.23,1.86,5.82$ and 6.02 respectively (Table 2). In Table-1, the average number of irrigation was 6.02. But in 
Rajshahi, it was more than 19 times. Naturally, Rajshahi is a dry area. Moreover the farmers of that area irrigated their betel leaf plot manually carrying water with different pots. For this reason more number of irrigation was needed.

Table 2. Agronomic practices of betel leaf production followed in the study areas.

\begin{tabular}{l|c|c|c|c|c}
\hline \multirow{2}{*}{ Agronomic practices } & \multicolumn{5}{|c}{ Locations } \\
\cline { 2 - 6 } & Barisal & Chittagong & Rajshahi & Kustia & All area \\
\hline $\begin{array}{l}\text { Month of plantation: (\%) } \quad \text { July } \\
\quad \text { August }\end{array}$ & 50 & 75 & 25 & - & 37 \\
$\quad$ September & 33 & - & - & 20 & 5 \\
$\quad$ October & 17 & 25 & 75 & 80 & 11 \\
Earthing of soil (No./year) & 3.4 & 2.0 & 1.5 & 1.0 & 2.0 \\
Oilcake application & 5.0 & 5.4 & 2.8 & 3.8 & 4.2 \\
(No./year) & 1.9 & 2.1 & 2.0 & 1.6 & 1.9 \\
Weeding (No./year) & 4.0 & 8.4 & 5.8 & 2.7 & 5.9 \\
Insecticides use (No./year) & 1.9 & 0.8 & 19.2 & 2.2 & 6.0 \\
Irrigation (No./year) & 165820 & 172841 & 123845 & 134652 & 149290 \\
Number of vine per ha & 15.24 & 14.25 & 20.32 & 19.82 & 17.38 \\
Plant distance (cm) & \multicolumn{5}{c}{} \\
\hline
\end{tabular}

\section{Input use}

Human labour was required for seed(vine) planting, application of manures, fertilizing, spraying, weeding, irrigation and harvesting. On an average, 1665 mandays/ha was required for betel leaf cultivation (Table 3). The number of human labour varied from one year to another year due to change in the number of weeding, spraying insecticides, irrigation, and harvesting. Use of human labour was highest in third year old boroj. It might be due to more use of cowdung, TSP and irrigation. Respondent farmers used cowdung $2.55 \mathrm{t} / \mathrm{ha}$. The highest $9.85 \mathrm{t} / \mathrm{ha}$ was used during the second year while the lowest $0.32 \mathrm{t} / \mathrm{ha}$ was used in 11-15 years boroj. It was observed that farmers having 16-22 old boroj did not use cowdung at all may be due to the low response in production. On an average, farmers used $2.5 \mathrm{t} / \mathrm{ha}$ oilcake in betel leaf cultivation. The highest amount of oilcake 3.2 t/ha was used in the boroj which were 16-22 years of age while the lowest in 3 years old boroj. The betel leaf farmers applied chemical fertilizers like urea $202 \mathrm{~kg} / \mathrm{ha}$, TSP $296 \mathrm{~kg} / \mathrm{ha}$, MoP $33 \mathrm{~kg} / \mathrm{ha}$ and gypsum 35 $\mathrm{kg} / \mathrm{ha}$. The application of urea and TSP was observed to be higher in the case of 16-22 years old boroj. 
Table 3. Per hectare input used for betel leaf cultivation in the study areas.

\begin{tabular}{l|c|c|c|c|c|c|c|c|c}
\hline \multirow{2}{*}{ Parameters } & \multicolumn{8}{c}{ Period of cultivation (Year) } \\
\cline { 2 - 11 } & $1^{\text {st }}$ & $2^{\text {nd }}$ & $3^{\text {rd }}$ & $4^{\text {th }}$ & $5^{\text {th }}$ & $6-10$ & $11-15$ & $16-22$ & All \\
\hline Observations & $n=19$ & $n=23$ & $n=48$ & $n=44$ & $n=37$ & $n=55$ & $n=30$ & $n=11$ & $n=256$ \\
$\begin{array}{l}\text { Human labour } \\
\text { (mandays) }\end{array}$ & 1385 & 1509 & 1694 & 1619 & 1693 & 1598 & 1522 & 1491 & 1665 \\
$\quad$ & & & & & & & & & \\
$\quad$ Own & 662 & 655 & 790 & 666 & 718 & 667 & 605 & 679 & 718 \\
$\quad$ Higher & 723 & 854 & 904 & 953 & 975 & 931 & 917 & 812 & 947 \\
Seed(Vine) & 123748 & & & & & & & & \\
Cowdung(ton) & 5.5 & 9.9 & 3.7 & 2.2 & 4.9 & 3.2 & 3.8 & - & 2.5 \\
Oilcake(ton) & 2.4 & 2.5 & 2.3 & 2.3 & 2.3 & 2.6 & 2.5 & 3.2 & 2.5 \\
Fertilizer & & & & & & & & & \\
(kg): & & & & & & & & & \\
Urea & 117 & 207 & 165 & 202 & 213 & 211 & 190 & 248 & 202 \\
TSP & 386 & 321 & 343 & 276 & 237 & 208 & 239 & 452 & 296 \\
MP & 21 & 56 & 37 & 24 & 22 & 20 & 63 & 15 & 33 \\
Gypsum & 33 & 87 & 53 & 110 & 36 & 35 & 9 & 45 & 55 \\
Others* & 26 & 20 & 5 & 17 & 12 & 12 & - & 2 & 12 \\
\hline
\end{tabular}

* Others indicate DAP, Zn, Boron, etc.

\section{Cost of production}

The cost of production included human labour, boroj making materials, seed (vine), manures, fertilizers, pesticides, irrigation, insecticides, etc. Rental value of land was treated as fixed cost and was included in the total costs. Seed (vine) cost was needed only for the first year. The highest cost (Tk 1088333/ha) was incurred in the first year due to initial investment on seed (vine) and boroj making materials. The lowest cost (Tk 885035/ha) was observed for the boroj aged ranged from 11-15 years (Table 4). Among the cost items of betel leaf cultivation human labour incurred the highest cost (50\%) followed by boroj materials cost (26\%).

\section{Return}

For estimating the yield of betel leaf, data were collected from the survey plot on the basis of local unit like bira, Sali, gadi, kuri, pon etc. After that yield data were converted into ton per hectare on the basis of average weight of betel leaf. On an average, the weight of 265 number of betel leaf is one kilogram (Moniruzzaman, 2008). On review of Table 3 , it is observed that the yield started increasing during $2^{\text {nd }}$ to $5^{\text {th }}$ year and declined form thereafter. Among the betel leaf boroj, 


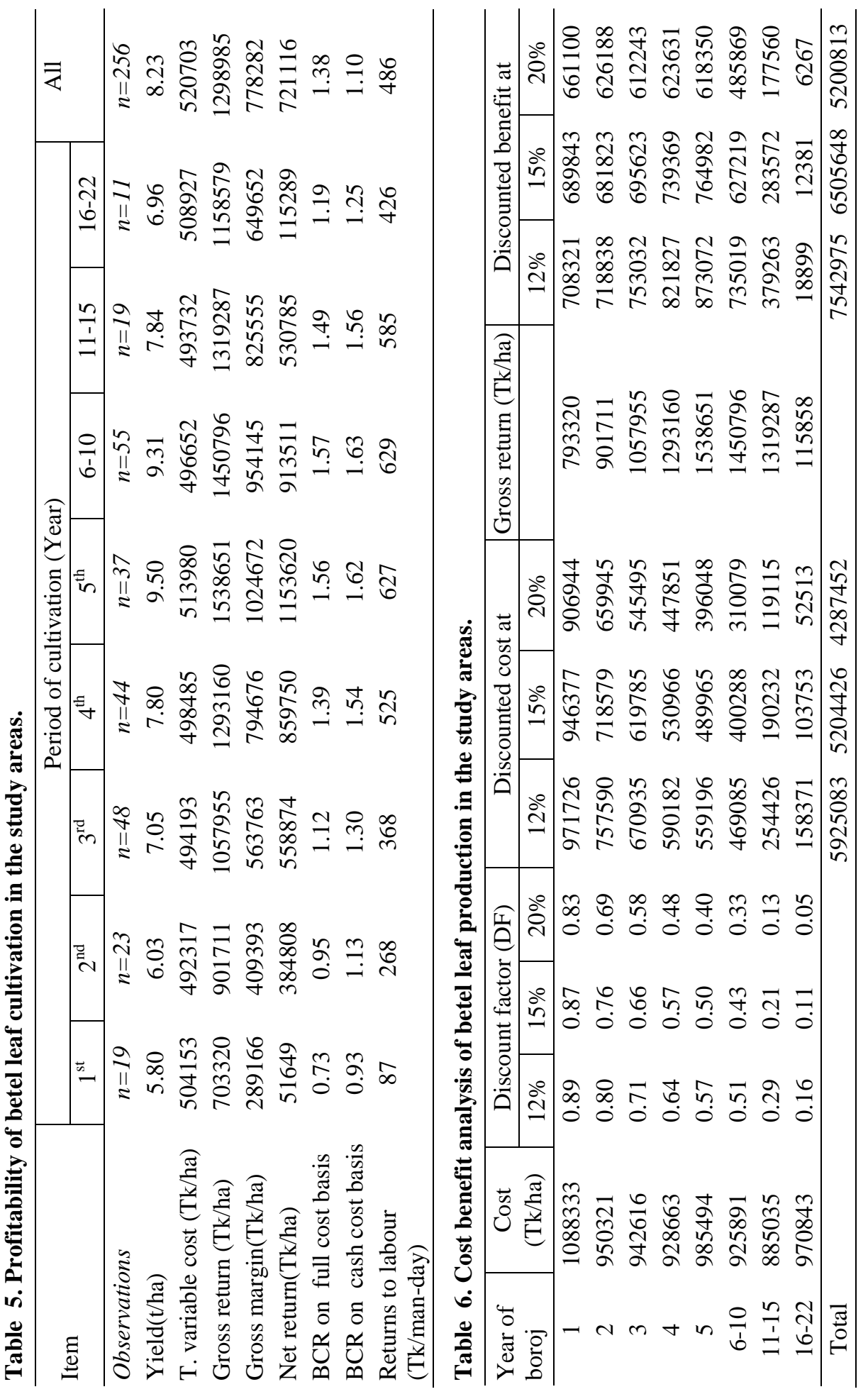


the highest yield $(9.50 \mathrm{t} / \mathrm{ha}$ ) was found in the 5 years old boroj and the lowest yield (5.80 t/ha) in one year old boroj (Table 5). On an average, $8.23 \mathrm{t} / \mathrm{ha}$ betel leaf was harvested. Which was higher than national yield of $5.81 \mathrm{t} / \mathrm{ha}$ (BBS, 2011). Gross return was calculated through multiplying yield and price of betel leaf. Betel lean price was varied area to area and season to season. This ranged from Tk. 20 to Tk. 120. Average gross return was Tk. 1298985/ha in which the highest gross return was received in $5^{\text {th }}$ year (Tk. 1538651/ha) and the lowest in $1^{\text {st }}$ year (Tk. 793320/ha). Average gross margin was found (Tk. 778282/ha). On an average, Tk. 721116 was found as net return. Highest net retrun Tk. 1153620 was found in $5^{\text {th }}$ year. Average returns to labour was found to be Tk. 486 which was higher than their opportunity cost (Tk 300/day). It was evident that labour use in betel leaf cultivation was profitable than the opportunity cost of labour.

\section{Returns to investment}

Normally, the best discount rate to use is the "opportunity cost of capital"- i.e., the profitability of the last possible investment in an economy given the total available capital. In most developing countries it is assumed to be somewhere between 10-12\% (Gittinger, 1977). To calculate a range of benefit-cost ratio (BCR), net present worth (NPV) and internal rate of return (IRR), the costs and returns were discounted at $12 \%, 15 \%$ and $20 \%$ rate of interest.

Firstly, the cost and benefit streams were discounted in order to find their present worth. Dividing the present worth of the gross benefits by the present worth of the gross cost it was found that the benefit cost ratio to be $1.27,1.25$ and 1.21 at $12 \%, 15 \%$ and $20 \%$ rate of interest. Net present worth is the difference between the present worth of benefits and present worth of costs. The discounted gross benefit has present worth at $12 \%, 15 \%$ and $20 \%$ rate of interest were Tk. 7542975/ha, Tk. 6505648/ha Tk. 5200813/ha and the discounted gross cost has present worth of Tk 5925083/ha, Tk 5204426/ha, Tk 4287452/ha (Table 6). The difference between the two net present worth at $12 \%, 15 \%$ and $20 \%$ discount rate is Tk 1617892/ha, Tk 1301222/ha, Tk 913361/ha. It signifies that betel leaf cultivation in the study areas is profitable.

Table 7. Rates of returns on investment in betel leaf production in the study areas.

\begin{tabular}{l|cc|c}
\hline \multirow{2}{*}{ Item } & \multicolumn{3}{|c}{ Discount factor (DF) } \\
\cline { 2 - 4 } & $@ 12 \%$ & $@ 15 \%$ & @ 20\% \\
\hline BCR & 1.27 & 1.25 & 1.21 \\
NPV (Tk) & 1617892 & 1301222 & 913361 \\
IRR (\%) & & $62 \%$ & \\
\hline
\end{tabular}

The IRR for the investment is that discount rate which nullifies the present worth of cash flows and outflows. It represents the average earning power of 
the money used in the project over the project life. In betel leaf project, IRR is $62 \%$. It is acceptable, because it is much higher than the opportunity cost of capital (Table 8).

\section{Sensitivity Analysis}

To make a valid generalization it was necessary to conduct sensitivity analysis. This table has been reworked separately to see what happens on the profitability of betel leaf under varying conditions. The cost of betel leaf cultivation was considered constant, while benefit decreases at the rate of $10 \%$ or if benefit of the betel leaf cultivation remains the same but all costs increase at the rate of $10 \%$ then what would be the outcome.

Table 8. Result of sensitivity analysis of betel leaf cultivation in the study areas.

\begin{tabular}{l|c|c|c}
\hline \multirow{2}{*}{ Situation } & \multicolumn{3}{c}{ Discount measures } \\
\cline { 2 - 4 } & BCR at $12 \%$ & NPV at $12 \%$ & IRR (\%) \\
\hline $\begin{array}{l}\text { Base parameter } \\
\text { Decrease of return: } \\
10 \%\end{array}$ & 1.27 & Tk. 1617892 & 62 \\
Increase of gross cost: & 1.04 & Tk. 271086 & 37 \\
$10 \%$ & 1.16 & Tk. 102583 & 39 \\
\hline
\end{tabular}

The results of sensitivity analysis considering the above mentioned situation are presented in Table 8. It was revealed from the table 7 that BCR of betel leaf is greater than one, NPV is positive at $12 \%$ discount rate and IRR is also higher than the opportunity cost of capital. This implies that if the returns decrease at $10 \%$ the cost of betel leaf remains unchanged investment in betel leaf is profitable from the point of view of the owner. Again, BCR of the betel leaf is greater than one. NPV is positive and IRR is higher than the opportunity cost of capital, if gross cost increases at $10 \%$ the returns remain same. This means that the owner of betel leaf boroj can also make profit if all costs slightly increase in near future. The result of the study indicates that the owners of betel leaf boroj can earn profits under changing situation.

\section{Constraints}

Every farmer opined one or more than one problems (Table 9). Leaf rot disease was a common problem in the study areas. About $79 \%$ farmers opined that it is a serious problem for betel leaf cultivation. High price of boroj materials was another problem reported by the farmers. Many farmers reported that vine died at the end of the vine and sometimes 2-3 ft upper was a common problem which hampered the betel leaf production. About $45 \%$ farmers faced the problem of capital shortage during betel leaf cultivation. Cumbersome procedure of 
institutional credit was also a common problem in the study area. Price of betel leaf is very low during rainy season i.e. during the months of June to August. Regarding seed (vine), respondents had mentioned the problem of nonavailability of quality seed. They did not know about the modern varieties of betel leaf. Though BARI released two betel leaf varieties but these were not reached to the farmer's field. Farmers used much quantity of oilcake in their boroj. Some of the responded opined that price of oilcake was very high. For this reason some of the farmers were unable to apply oilcake according to their desired level. Huge number of labour is required for betel leaf cultivation. About $17 \%$ farmers faced the problem of non-availability of labour. Non-availability of irrigation water was also a problem opined by $13 \%$ respondent. It is essential to irrigate the betel leaf boroj during dry period. High price of insecticides was also mentioned by $7 \%$ farmers. Besides, some farmers mentioned that insect infestation, excess cold, lack of transportation facilities were also the constraints of betel leaf cultivation.

Table 9. Constraints faced by the respondent betel leaf growers in the study areas.

\begin{tabular}{l|c}
\hline Constraints & \% of responses $(n=256)$ \\
\hline 1. Infection of leaf rot disease & 79 \\
2. High price of boroj materials & 56 \\
3. Seed (vine) died & 52 \\
4. Lack of capital & 45 \\
5. Low price of betel leaf & 41 \\
6. Non-availability of modern varieties & 32 \\
7. High price of oilcake & 21 \\
8. Non-availability of labour & 17 \\
9. Non-availability of irrigation water & 13 \\
10. High price of insecticides & 7 \\
11. Others* & 27
\end{tabular}

* Others indicate insect infestation, excess cold, lack of transport facilities etc.

\section{Conclusion and Recommendation}

The study has estimated the agronomic practices, profitability, returns to investment of betel leaf cultivation and constraints to its cultivation at farm level. The benefit cost ratio, net present worth and internal rate of return indicate that betel leaf cultivation is profitable. Sensitivity analysis also indicates that the owners of betel leaf boroj can earn profit under changing situation. Although betel leaf cultivation is profitable, but farmers faced various problems such as infection of leaf rot disease, high price of boroj materials, vine died, lack of 
capital, low price of betel leaf, high price of oilcake, non-availability of modern variety, labour scarcity, and lack of irrigation water.

For controlling leaf rot disease of betel leaf, pathologist may conduct research on this aspect. It is also imperative to carry out more research on developing high yielding varieties of betel leaf and develop appropriate production technologies for maximizing the yield as well as income and minimizing the cost. Extension works with publicity need to be strengthened to popularize the modern varieties of betel leaf in order to expand its cultivation area.

\section{References}

Ahmed, A.U. 1985 Disease Problems of Betel Leaf Vine in Kushtia Area, Plant Pathology Division, BARI, Joydebpur, Gazipur.

Anonymous, 1984. Export form Bangladesh during the fiscal year 1970-71 to 1983-84, Export promotion Bureau, Motigheel commercials Area, Dhaka, Bangldesh.

Bangladesh Bureau of Statistics, 2011. Yearbook of Agricultural Statistics of Bangldesh. Statistical Division, Ministry of Planning. GOB. P. 76.

Gittiner, J.P. 1977. Economic Analysis of Agricultural Project. A World Bank Publication.]

Islam, M.N and S.M. Elias (1991), Production and Marketing of Betel leaf in selected areas of Bangladesh, Research Report No. 16, Agricultural Economics Division, BARI, Joydebpur, Gazipur.

Moniruzzaman, M.S. Rahman, M.A Hossain and Q.M. Alam(2008). Betel Leaf Production and Its Market Potential on National and International Market. Annual Research Report, Agricultural Economics Division, BARI, Joydebpur, Gazipur. 